\title{
TRH Gene
}

National Cancer Institute

\section{Source}

National Cancer Institute. TRH Gene. NCI Thesaurus. Code C39668.

This gene plays a regulatory role in the biosynthesis of thyroid stimulating hormone. 